\title{
Blocking evil infinites: A note on a note on a Peircean strategy
}

\author{
Frederik Stjernfelt \\ Humanomics Center, Department for Arts and Culture Studies \\ University of Copenhagen \\ Karen Blixens Vej 1, DK-2300 Copenhagen S, Denmark \\ e-mail: stjern@hum.ku.dk
}

\begin{abstract}
This brief note considers Peirce's strategy of terminating potentially evil infinities - concerning relations, continuous predicates, leading principles, habits - by appeal to the Nota Notae principle.
\end{abstract}

Keywords: Nota Notae, evil infinity, relations, formal ontology, Charles Peirce

Hegel famously coined the term "schlechte Unendlichkeit" to address the issue of a proliferating process of repetitive thought without end - which should be avoided. ${ }^{1}$ A similar argument is often marshalled in philosophy in order to rule out excessive conceptuality. Regarding the reality of relations, thus, it can be counterargued that if you accept real relations, then what about the relations between the relation and its relata? And what about the relations between those second-order relations and the firstorder relation - that calls for third-order relations and so on ad infinitum, ultimately constituting a potential infinity. But as reality is taken not to contain infinities, such processes are supposed to have no reality counterparts. In the case of relations then, better avoid an evil infinity by refusing to ascribe reality to any relations at all.

1 "Etwas wird ein Anderes, aber das andere ist selbst ein Etwas, also wird es gleichfalls ein Anderes, und so fort bis ins Unendliche.

Diese Unendlichkeit ist die schlechte oder negative Unendlichkeit, indem sie nichts ist, als die Negation des Endlichen, welches aber ebenso wieder entsteht, somit ebensosehr nicht aufgehoben ist - oder diese Unendlichkeit drückt nur das Sollen des Aufhebens des Endlichen aus. Der Progreß ins unendliche bleibt bei dem Aussprechen des Widerspruchs stehen, den das Endliche enthält, daß es sowohl Etwas ist als sein Anderes, und ist das perennierende Fortsetzen des Wechsels dieser einander herbeiführenden Bestimmungen." (Hegel 1830, Enzyklopädie der philosophischen Wissenschaften im Grundrisse, \$93-\$94). Retrieved from http://www.zeno.org/ Philosophie/M/Hegel,+Georg+Wilhelm+Friedrich/Enzyklopädie+der+philosophischen+Wis senschaften $+\mathrm{im}+$ Grundrisse. 
In Peirce's philosophy and semiotics - accepting the reality of relations - a recurring strategy appears to rule out such idling processes by reaching instead a rock bottom. That strategy, however, is not the Hegelian trick of Aufhebung. What does it consist in?

Let us take a few examples to give an idea. In his mature, deep-digging investigation of the structure of propositions ("Dicisigns") taking its departure from the 1903 Syllabus, ${ }^{2}$ one strategy is that of emptying a proposition for semantic content in order to reach its bare fundamental structure. Such emptying may be undertaken by means of hypostatically abstracting its predicates in order to constitute additional subjects. ${ }^{3}$ Thus "Cain killed Abel" may be translated into "Cain stands in the relation of Killing to Abel". Instead of the two-place predicate "X kills Y", a three-place predicate "X stands

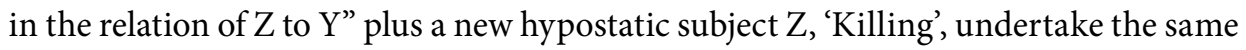
task of description. In principle, such transcription is indefinite - the next step would be to translate the three-place predicate into a four-place predicate: " $X$ stands in the relation $\mathrm{Z}$ of standing in the relation Q to $\mathrm{Y}^{\prime}$. It is easy to see that this procedure may be continued into a schlechte Unendlichkeit. Instead, Peirce's argument goes that there is absoluteluy no difference between standing in a relation to something and standing in the relation of standing in a relation to something (Stjernfelt 2014: 88-89). So here, already the first step reached rock bottom, and " $\mathrm{X}$ stands in the relation of $\mathrm{Z}$ to $\mathrm{Y}$ " must be accepted as a primitive, not accessible to further such analysis.

Another case is that of the leading principle of inferences. As a fundamental claim of the philosophy of logic, inferences are deemed valid reasonings only if they follow and acknowledge a general leading principle securing that not only in the particular case, but in a generic class of cases like premises lead to like conclusions. That leading principle is not counted among the premises of the inference but is rather the generic diagrammatic structure which makes evident that those premises do lead to the conclusion. A leading principle may be made explicit as a logical doctrine (e.g. Modus Ponens), but in most ordinary cases, the leading principle is accepted tacitly, yet subject to virtual self-control (here, Peirce is walking on a knife's edge). Would it be better if all reasoners were taught logical doctrine, becoming able to make explicit their leading principles? Not necessarily, saw Peirce, ${ }^{4}$ because the very act of making explicit the leading principle will itself depend upon a leading principle (already e.g. "Algebra of logic", 1880, 3.166). This fact, however, does not make logic obsolete because of dependence upon an infinite abyss of still deeper leading principles. Rather, the leading principle of a leading principle is but that leading principle itself.

2 The Syllabus was never published in its entirety, but various selections can be found in CP (Vols. 1, 2), as well as EP, Chs. 18-23.

3 In a letter to Lady Welby, 14 December 1908 (Peirce 1966: 396-397).

4 As argued by Pietarinen and Bellucci in a recent paper (in press). 
A further version of this rock-bottom principle pertains to the famous "unlimited semiosis", so beloved by Derrida and deconstructivists: the principle that the interpretant of a sign is, in itself, a sign of the very same object. This basic definition makes the sign relation recursive and makes possible indefinite chains of signs. Such a chain, however, is not autonomized and isolated from reality. Quite on the contrary, as the definition maintains, a single such chain pertains to the same object and potentially enriches the description of that object, ultimately to converge in a final interpretant of that object (that is, if the sign using community sticks to basic, overarching principles of sign development). ${ }^{5}$ But, given the sign definition, how could there be a final interpretant not itself a sign? Here, Peirce's pragmatism famously holds that the final meaning of a sign consists in the set of action habits which a rational person would adopt given that the conceived sum of effects of the sign is true. ${ }^{6}$ And that set of action habits are not themselves a sign (even if signs of it may, of course, be made). Again, the habit of a habit is that habit itself.

All of these check blocks are particular versions of a general scholastic principle discussed by Peirce, the so-called Nota Notae principle, referring to the claim that "Nota notae est nota rei ipsius": the predicate of a predicate is a predicate of the thing itself.? Originating in Aristotle's Categories, the principle was later taken up by Wolff, Kant, and Stuart Mill. The Latin version just given Peirce finds in Kant. Of course, here the notion 'predicate' should be taken as referring to the meaning of the predicate, not the predicate word or expression itself. If it is taken to refer to the token or type of the predicate expression, the Nota Notae principle would be wrong (the fact that a predicate token is written in red ink does not imply that the object referred to is written in red ink; the fact that a predicate type stems from the 16th century does not imply that the object it refers to stems from that century, etc.). But if a certain colour is very rare, it does follow that objects having that colour are very rare. Or, Peirce's standard example, if humans are mortal, and Enoch is human, it follows that Enoch is mortal. Here, the Nota Notae gives rise to a syllogism: 'mortal' is a second-order predicate of the first-order-predicate 'human', also holding for those which the first-order predicate holds for. The particular

5 Cf. Stjernfelt 2014, Ch. 11.

${ }_{6} \quad$ Regarding these aspects of Peirce's concept of habit, see Pietarinen and Bellucci (in press) and Stjernfelt (in press).

7 In 1901, Peirce writes in a small article on the Nota Notae in Baldwin's Dictionary of Philosophy and Psychology: "The logical principle Nota notae est nota rei ipsius, that is, the predicate of the predicate is the predicate of the subject, which is laid down in several places by Aristotle as the general principle of syllogism. The principal passages are as follows: 'When one thing is predicated of another as its subject, whatever is said of the predicate can also be said of the subject' (Categ., iii. $1 \mathrm{~b}$ 10). 'Whatever is said of the predicate will hold also of the subject' (Categ., v. 3 b 4)." (“Nota Notae”, 1901, 2.590)

Othertimes, Peirce simply identifies the Nota Notae with the transitivity of the copula: $\mathrm{A}=\mathrm{B}, \mathrm{B}=\mathrm{C} \rightarrow \mathrm{A}=\mathrm{C}$. 
use of the principle in Peirce addressed here, however, highlights special cases where the first- and second-order predicates of the Nota Notae are the same. Oftentimes, such cases will be meaningless (the red colour of the red colour, etc.): many predicates do not apply to themselves. Other predicates unproblematically apply to themselves (an utterance of an utterance, leading to any level of quotations of quotations; a sign of a sign, leading to any level of description of the sign's object). The issue of which predicates are thus self-applicable is not a formal one, decidable from formal criteria, but rather pertains to the regional ontology to which that predicate belongs. Here, Peirce's use of the Nota Notae focuses on a subset of those special cases where (1) the predicate is self-applicable and (2) its self-application does not change its meaning at all. While the utterance of an utterance is a special utterance, namely a quotation, the habit of a habit is simply that same habit. The former still conforms to the Nota Notae principle (because being quoted is also a property of the first utterance), but the latter belongs to that special subset of self-applicable predicates where $\mathrm{f}^{2}(x)=\mathrm{f}(x)$, so to speak. All of those are continuous in the special sense Peirce used when picking the term 'continous predicates': applying the predicate to itself gives but the same predicate, just like joining one continuous line to another gives a continuum of the same power.

They form a rock bottom providing Peirce's seemingly byzantine logic and semiotics with a fundamental inventory of formal ontology: relations, continuous predicates, leading principles, habits are not further analysable and must be taken to belong to the basic furniture of ontology. If we accept Peirce's argument, the next question follows: how much belongs to such furniture?

\section{References}

Peirce, Charles Sanders 1966. Selected Writings. (Wiener, Philip P., ed.) New York: Dover Publications.

- 1982. Writings. (Vols. 1-4; 8.) Bloomington: Indiana University Press.

- 1998[1931-1958]. Collected Papers. (Vols. 1-8) (Hartshorne, Charles; Weiss, Paul; Burks, Arthur W. eds.) London: Thoemmes Press. [In-text references are to CP, followed by volume and paragraph numbers.]

- 1998a. The Essential Peirce. Vol. 2 (1893-1913). (Houser, Nathan; Kloesel, Christian, eds.) Bloomington: Indiana University Press. [In-text references are to EP.]

Pietarinen, Ahti-Veikko; Bellucci, Francesco (in press): Habits of reasoning. On the grammar and critics of logical habits. In: West, Donna E.; Anderson, Myrdene (eds.), Habit: Before and Beyond Consciousness. Dordrecht: Springer.

Stjernfelt, Frederik 2014. Natural Propositions: The Actuality of Peirce's Doctrine of Dicisigns. Boston: Docent Press.

- in press. Dicisigns and habits: Implicit propositions and habit-taking in Peirce's pragmatism. In: West, Donna E.; Anderson, Myrdene (eds.), Habit: Before and Beyond Consciousness. Dordrecht: Springer. 
522 Frederik Stjernfelt

\section{Блокировка «дурных бесконечностей»: заметка об одной заметке о стратегии Пирса}

В этой короткой заметке рассматривается пирсовская стратегия блокировки потенциально „дурных бесконечностей“ (касающихся отношений, непрерывных предикатов, ведущих принципов, привычек (habits)) с помощью принципа nota notae.

\section{Halbade lõpmatuste blokeerimine: märkus üht Peirce'i strateegiat puudutava märkuse kohta}

See lühimärkus puudutab Peirce'i strateegiat potentsiaalselt "halbadele lõpmatustele" - mis puudutavad suhteid, kestvaid predikaate, juhtpõhimõtteid, tavasid - lõpu tegemiseks nota notae põhimõtet appi võttes. 